\title{
A Zero Carbohydrate, Carnivore Diet can Normalize Hydrogen Positive Small Intestinal Bacterial Overgrowth Lactulose Breath Tests: A Case Report
}

\section{Peter Martin}

FunMed Gothenburg Sweden

Martina Johansson ( $\square$ martina.akj@gmail.com )

Institution for Medicine and health https://orcid.org/0000-0001-7031-2892

\section{Annelie Ek}

FunMed Gothenburg

\section{Research article}

Keywords: Zero carbohydrate, carnivore diet, small intestinal bacterial overgrowth, SIBO, lactulose hy-drogen breath testing, nutritional intervention.

Posted Date: January 19th, 2021

DOl: https://doi.org/10.21203/rs.3.rs-148500/v1

License: (c) (7) This work is licensed under a Creative Commons Attribution 4.0 International License. Read Full License 


\section{Abstract}

Background: Small intestinal bacterial overgrowth (SIBO) is a clinical condition characterized by an excessive bacterial growth in the small intestine. Clinical symptoms might be non-specific (dyspepsia, bloating or abdominal discomfort). Nevertheless, SIBO can cause severe malabsorption, serious malnutrition, immune reactions, and deficiency syndromes. This retrospective case report introduces six patients with positive lactulose hydrogen SIBO breath tests. The patients chose between different therapeutic options and willingly consented to a nutritional intervention, based on a zero carbohydrate, zero fibre, carnivore diet, extended over two to six weeks of time. The rationale for this dietary approach was based on the idea that opportunistic, carbohydrate favouring bacteria and methanogens proliferate in the small intestines if the natural barriers in the digestive tract have been weakened due to stress, illness, medication, etc. A zero carbohydrate, carnivore diet, consisting of animal fats and protein, could essentially eliminate these carbohydrate favouring bacteria through starvation while still providing plenty of both calories and nutrients.

Methods: six patients from our functional medicine clinic followed a strict zero carb, zero fiber, carnivore diet for 2-6 weeks. A lactulose breath test was performed immediately before and after the dietary change as well as extensive medical testing.

Results: five patients that followed the carnivore diet for four weeks or longer tested negative for SIBO, and the one patient that only endured the diet for two weeks had a near complete eradication of her hydrogen elevation. Methane values were generally low both before and after the dietary treatment, but there was a significant decrease in patients 3 and 5.

Conclusions: The carbohydrate, zero fibre, carnivore diet shows great potential for being a readily available, cost-effective, and equally effective alternative treatment for SIBO. According to our observations it also results in better satisfaction after meals, decreases cravings for sweets and generate weight-loss in patients where it is needed.

\section{Background}

Small intestinal overgrowth (SIBO) is denoted as an increase in overall bacterial population in the small intestine, particularly in types of bacteria not commonly found in that part of the digestive tract. There are three different types of SIBO where some bacteria produce hydrogen, others methane and the third group hydrogen sulphide.[1] Hydrogen- and methane producing bacteria are easily detected with a lactulose breath test. The symptoms typically include gastrointestinal issues like diarrhoea, steatorrhea, chronic abdominal pain, bloating, and flatulence.[2] It is increasingly popular to treat these symptoms with dietary changes; elemental diet as well as low FODMAP is continuously being used with a high success rate in remission. Elemental diet is a mixture of pre-digested amino-acids, fats, sugars, and vitamins in liquid form, while low FODMAP is a diet low in Fermentable Oligosaccharides, Disaccharides, Monosaccharides, and Polyols, as these nutrients are poorly absorbed and commonly cause gut issues.[3] Low FODMAP is not relevant as a SIBO treatment, but rather to give some relief from IBS (irritable bowel syndrome). SIBO and 
IBS are oftentimes mentioned in conjunction, but they are not always dependent on each other. According to studies SIBO is the most common cause of IBS, but not the one and only cause. Other explanations for IBS could be, for example, celiac disease or dysbiosis in the colon.[4]

The main mechanisms restricting bacterial colonization in the upper gut are the gastric acid barrier and mucosal and systemic immunity. When these mechanisms fail, bacterial overgrowth can develop.[5] Another cause for bacterial overgrowth in the small intestine could be due to inefficient migrating motor complex (MMC). Bacteria, which normally should have been transported to the colon, remain in the small intestine, and reproduce there.[6]

The functional medicine model of care provides an operating system that works to reverse illness, promote health, and optimize function by addressing underlying causes, symptoms, and functional imbalances in interconnected biological networks. [7] The functional medicine approach to SIBO includes treatment of underlying disease, nutritional support, and broad-spectrum antibiotics. However, antibiotics increase the risk of antibiotic resistance and undermine a healthy gut flora, thus compromising the entire immune system.[8]

As an alternative approach the patients were recommended to follow a zero carbohydrate, zero fibre, carnivore diet for two to six weeks. The theory is that SIBO thrive on carbohydrates and fibre and starve when these macronutrients are eliminated. According to a study viewing Escherichia coli metabolism in the gut, the bacteria grows best on sugars. [25]

The carnivore diet has gained popularity in recent years, as the extreme end of the spectrum of low carbohydrate diets. The diet is commonly utilized by people with overly sensitive immune systems and treatment resistant obesity. Even though there is evolutionary evidence for animal-based nutrition in our species $[9,10]$, there are no published original research articles or clinical reports on the therapeutic effect of a carnivore diet, and one reason for this might be the controversial status of an exclusively animal based diet. However, this case report from our functional medicine clinic, is not about the long-term effect of this diet, and our purpose is not to promote a zero carbohydrate, carnivore diet for any reason, but to present evidence of its effectiveness as a cost effective, readily available, short-term nutritional therapy to normalize a hydrogen positive result in the SIBO lactulose breath test.

\section{Methods}

This case report is a retrospective review of ongoing clinical work, with the SIBO breath tests recorded between October 2018 to August 2020. All six subjects were regular patients at a functional medicine [7] clinic (FunMed) in Gothenburg, Sweden, and followed the structured process used by this clinic. The subjects consented to scientific publication of the collected data in writing. After a first visit to an M.D. (Dr Peter Martin) they all performed an extensive blood panel (Unilabs, Sweden), GI Effects comprehensive stool test (Genova Diagnostics, UK), Nutrient and Toxic Element Profile (NutrEval, Genova Diagnostics, UK), ImuPro IgG antibody screening for food intolerances (CTL \& Ortholabor $\mathrm{GmbH}$, Germany), and a SIBO lactulose hydrogen/methane breath test (Biolab, UK). The SIBO breath test was performed before and 
directly after (on the last day of) the dietary change. No antibiotic drugs or antimicrobial agents were used during the treatment period. There was no commercially available diagnostic tool for hydrogen sulphide SIBO when these patients were treated.

\section{The therapeutic diet}

All patients were instructed to follow a strict zero carbohydrate, zero fibre, carnivore diet for two to six weeks. The diet was exclusively composed of animal fats and proteins: all types of meat, organ meats, fish, poultry, tallow, lard, and eggs. No vegetables, vegetable oils or dairy products except for butter was included. Extra intake of table salt was recommended to compensate for sodium loss. The patients could drink coffee, tea, and water, but no sweetened beverages or diet sodas. No caloric limit or other restrictions were implied, the patients were encouraged to eat as much and as often as they wanted.

\section{Lactulose Hydrogen and Methane Breath Test}

Breath samples $(n=10)$ were collected using glass vacuum vials with rubber tops that was pushed on a rubber-clad needle. Patients were instructed to, in the morning after $a>12$ hour overnight fast, breath into a standardized plastic bag connected to the needle and sample their breath at $\mathrm{t}=0 \mathrm{~min}$, and then ingest a lactulose solution. Subsequent breath samples were collected at $t=20,40,60,80,100,120,140,160$ and 180 minutes. Preparation before the test is normally eating a zero carbohydrate, zero fibre diet the day before the test. The purpose for this is to starve the bacteria prior to the test to minimize ongoing gut fermentation.[11] In our case, the strict diet was instead followed for two to six weeks.

The sample was sent to Biolab medical unit in England for analysis and measurement of hydrogen and methane levels. Since lactulose unlike glucose is poorly absorbed in the intestines, but readily digested by gas producing bacteria, this test makes it possible to detect bacterial overgrowth in the entire gastrointestinal tract. A positive lactulose breath test was

defined as an increase of hydrogen at least $20 \mathrm{ppm}$ (parts per million) above baseline within the first 90 minutes, or if a hydrogen double peak was present, which is in line with our clinical experience reinforcing the SIBO diagnosis.

\section{NutrEval}

Urine samples were sent to Genova diagnostics laboratories to measure organic acids, which indicates cell functionality, nutrient balance, mitochondrial function, bacterial or fungus overgrowth and more. Blood samples were analysed for content of minerals, toxic elements, glutathione, CoQ10, vitamin D and fatty acids.

\section{GI Effects Comprehensive stool test}

Stool samples were sent to Genova diagnostics laboratories to analyse bacterial content in colon, digestion of macronutrients, parasites, inflammation, and more.

\section{ImuPro IgG antibody test}

Food intolerance test measuring IgG antibodies in blood for several foods. High levels of IgG antibodies 
indicate delayed allergic reaction to that specific kind of food. Blood samples were sent to CTL \& Ortholabor GmbH in Germany.

\section{Blood tests}

A comprehensive blood panel including kidney, thyroid and liver status, nutrients, lipid panel, CRP, insulin, glucose and more. Unilabs test labs were used for these analyses.

\section{Questionnaires}

The patients also filled out the FunMed clinic standard questionnaires about their lifestyle and current health status and went through the standard medical check-up. They all had individual health concerns that were taken into consideration as well as monitored and investigated.

\section{Results}

Background data on all six patients are shown in Table 1, while Table 2 is displaying the individual experiences of the carnivore diet intervention.

Figure 1 displays the results for the lactulose hydrogen/methane SIBO breath test for each patient before and after dietary treatment. Note the variation in scale on the $Y$ axis for patient 2 and patient 3 . The five patients that followed the carnivore diet for four weeks or longer tested negative for SIBO, and the patient that only endured the diet for two weeks had a near complete eradication of her hydrogen elevation. Methane values were generally low both before and after the dietary treatment, but there was a significant decrease in patients 3 and 5 .

Patient 2 and patient 4 followed the diet for four weeks whereas patient 3 followed it for two weeks, patient 5 for five weeks and patient 1 and 6 for six weeks. Patient 3 was treated with antibiotics (Xifaxan $550 \mathrm{mg}$ three times a day) for five weeks prior to the carnivore experiment, without noticeable effect on the hydrogen curve.

\section{Table 1.}

This table presents an overview of the patient's main concerns, nutrient deficiencies, select lab results and gastrointestinal status as well as their post-treatment SIBO test results. 


\begin{tabular}{|c|c|c|c|c|c|c|}
\hline Subjects & Main concerns & $\begin{array}{l}\text { Nutrient } \\
\text { deficiencies } \\
\text { \& select } \\
\text { other labs }\end{array}$ & $\begin{array}{l}\text { Presence } \\
\text { of } \\
\text { hippuric } \\
\text { acid in } \\
\text { urine }\end{array}$ & $\begin{array}{l}\text { Gastro- } \\
\text { intestinal } \\
\text { issues }\end{array}$ & $\begin{array}{l}\text { li } \\
\text { teria in } \\
\text { l test }\end{array}$ & $\begin{array}{l}\text { SIBO test } \\
\text { result after } \\
\text { diet } \\
\text { treatment } \\
\text { (weeks) }\end{array}$ \\
\hline $\begin{array}{l}\text { Pat.1 } \\
\text { Female } \\
22 \mathrm{y} / \mathrm{o}\end{array}$ & $\begin{array}{l}\text { Stubborn } \\
\text { fungal } \\
\text { infections and } \\
\text { rashes. }\end{array}$ & $\begin{array}{l}\text { Magnesium, } \\
\text { potassium, } \\
\text { folate, B12. }\end{array}$ & Yes & $\begin{array}{l}\text { Gluten } \\
\text { sensitivity and } \\
\text { stomach } \\
\text { discomfort }\end{array}$ & High & $\begin{array}{l}\text { Negative } \\
\text { test }(6 \\
\text { weeks })\end{array}$ \\
\hline $\begin{array}{l}\text { Pat.2 } \\
\text { Female } \\
65 \mathrm{y} / \mathrm{o}\end{array}$ & $\begin{array}{l}\text { pre-diabetic, } \\
\text { over-weight, } \\
\text { hypertension, } \\
\text { Cushing's } \\
\text { syndrome and } \\
\text { slight rosacea } \\
\text { tendencies. }\end{array}$ & $\begin{array}{l}\text { Magnesium, } \\
\text { zinc, folate, } \\
\text { B12, glycine. } \\
\text { Elevated } \\
\text { pyroglutamic } \\
\text { acid and 5- } \\
\text { HIAA. }\end{array}$ & Yes & $\begin{array}{l}\text { Bloating, } \\
\text { stomach } \\
\text { aches. }\end{array}$ & Normal & $\begin{array}{l}\text { Negative } \\
\text { test } \\
\text { (4 weeks) }\end{array}$ \\
\hline $\begin{array}{l}\text { Pat.3 } \\
\text { Female } \\
46 \mathrm{y} / \mathrm{o}\end{array}$ & $\begin{array}{l}\text { Chronic } \\
\text { constipation, } \\
\text { high stress, } \\
\text { poor sleep, dry } \\
\text { skin, slight } \\
\text { rosacea } \\
\text { tendencies. }\end{array}$ & $\begin{array}{l}\text { Magnesium, } \\
\text { potassium, } \\
\text { B2, B12, } \\
\text { glycine. } \\
\text { Elevated 5- } \\
\text { HIAA, } \\
\text { pyroglutamic } \\
\text { acid and 1- } \\
\text { methyl- } \\
\text { histidine. }\end{array}$ & Yes & $\begin{array}{l}\text { Chronic } \\
\text { constipation due } \\
\text { to slow bowel } \\
\text { movements }\end{array}$ & High & $\begin{array}{l}\text { Hydrogen } \\
\text { reduced } \\
\text { from } \\
150 \mathrm{ppm} \text { to } \\
20 \mathrm{ppm}(2 \\
\text { weeks). } \\
\text { Methane } \\
\text { reduced } \\
\text { from } 16 \text { to } \\
3 \mathrm{ppm} .\end{array}$ \\
\hline $\begin{array}{l}\text { Pat.4 } \\
\text { Female } \\
48 \text { y/o }\end{array}$ & $\begin{array}{l}\text { Cravings, } \\
\text { fatigue, chronic } \\
\text { diarrhoea. } \\
\text { Primary } \\
\text { diagnosis is } \\
\text { Graves' } \\
\text { disease. }\end{array}$ & $\begin{array}{l}\text { Magnesium, } \\
\text { zinc, } \\
\text { potassium, } \\
\text { vitamin D, } \\
\text { B1, B2, B6, } \\
\text { folate, B12. } \\
\text { Elevated 5- } \\
\text { HIAA, } \\
\text { pyroglutamic } \\
\text { acid and } \\
\text { carnosine. }\end{array}$ & No & $\begin{array}{l}\text { Chronic } \\
\text { diarrhoea }\end{array}$ & Normal & $\begin{array}{l}\text { Negative } \\
\text { test }(4 \\
\text { weeks) }\end{array}$ \\
\hline $\begin{array}{l}\text { Pat.5 } \\
\text { Female } \\
23 \text { y/o }\end{array}$ & $\begin{array}{l}\text { Fatigue, joint } \\
\text { pains, low } \\
\text { ferritin, } \\
\text { constipation, } \\
\text { OCD }\end{array}$ & $\begin{array}{l}\text { Magnesium, } \\
\text { potassium, } \\
\text { ferritin, B6, } \\
\text { folate, B12. }\end{array}$ & Yes & $\begin{array}{l}\text { Constipation. } \\
\text { Possibly due to } \\
\text { poor thyroid } \\
\text { function. }\end{array}$ & Normal & $\begin{array}{l}\text { Negative } \\
\text { test } \\
(5 \\
\text { weeks) } \\
\text { Methane } \\
\text { reduced } \\
\text { from } 5 \text { - } \\
0 \text { ppm. }\end{array}$ \\
\hline
\end{tabular}




\begin{tabular}{|c|c|c|c|c|c|c|}
\hline Subjects & Main concerns & $\begin{array}{l}\text { Nutrient } \\
\text { deficiencies } \\
\text { \& select } \\
\text { other labs }\end{array}$ & $\begin{array}{l}\text { Presence } \\
\text { of } \\
\text { hippuric } \\
\text { acid in } \\
\text { urine }\end{array}$ & $\begin{array}{l}\text { Gastro- } \\
\text { intestinal } \\
\text { issues }\end{array}$ & $\begin{array}{l}\text { li } \\
\text { eria in } \\
\text { l test }\end{array}$ & $\begin{array}{l}\text { SIBO test } \\
\text { result after } \\
\text { diet } \\
\text { treatment } \\
\text { (weeks) }\end{array}$ \\
\hline $\begin{array}{l}\text { Pat. } 6 \\
\text { Female } \\
49 \text { y/o }\end{array}$ & $\begin{array}{l}\text { Hypothyroidism } \\
\text { (Hashimotos), } \\
\text { rosacea, } \\
\text { endometriosis. }\end{array}$ & $\begin{array}{l}\text { Magnesium, } \\
\text { B1, B2, B3, } \\
\text { B6, biotin, } \\
\text { folate, B12, } \\
\text { glycine. } \\
\text { Elevated } \\
\text { arabinose, 5- } \\
\text { HIAA, } \\
\text { pyroglutamic } \\
\text { acid and 1- } \\
\text { methyl- } \\
\text { histidine. }\end{array}$ & Yes & $\begin{array}{l}\text { Slow bowel } \\
\text { movements. } \\
\text { Due to } \\
\text { hypothyroidism? }\end{array}$ & Normal & $\begin{array}{l}\text { Negative } \\
\text { test }(6 \\
\text { weeks })\end{array}$ \\
\hline
\end{tabular}

Table 2.

This table provides a brief overview of the individual experience for each patient.

\begin{tabular}{|c|c|c|c|}
\hline Subjects & Experiences & Physical side effects & $\begin{array}{l}\text { Weight loss \& } \\
\text { labs }\end{array}$ \\
\hline $\begin{array}{l}\text { Pat.1 } \\
\text { Female } \\
22 \text { y/o }\end{array}$ & $\begin{array}{l}\text { Enjoyed the diet and continued with a } \\
\text { low carbohydrate, low fibre diet. }\end{array}$ & Rapid weight loss & $\begin{array}{l}\text { Approx. } 2 \mathrm{~kg} \text {, } \\
\text { folate } 8 \mathrm{nM} \\
\text { (did not eat } \\
\text { liver) }\end{array}$ \\
\hline \multirow{2}{*}{$\begin{array}{l}\text { Pat.2 } \\
\text { Female } \\
65 \text { y/o }\end{array}$} & \multirow{2}{*}{$\begin{array}{l}\text { Found it boring without vegetables and } \\
\text { had cravings for sweets. Less bloating. } \\
\text { Better sleep. }\end{array}$} & \multirow[t]{2}{*}{ None } & $2 \mathrm{~kg}$ \\
\hline & & & $\begin{array}{l}\text { CRP down from } \\
5 \text { to } 0,77 \\
\text { HbA1c } 60 \text { to } 51\end{array}$ \\
\hline $\begin{array}{l}\text { Pat.3 } \\
\text { Female } \\
46 \text { y/o }\end{array}$ & $\begin{array}{l}\text { Experienced better energy and found } \\
\text { the diet tolerable. }\end{array}$ & $\begin{array}{l}\text { Body aches during the first } \\
\text { week. }\end{array}$ & $\begin{array}{l}2 \mathrm{~kg} \text { during } \\
\text { carnivore diet, } \\
11 \mathrm{~kg} \text { in total. }\end{array}$ \\
\hline $\begin{array}{l}\text { Pat.4 } \\
\text { Female } \\
48 \text { y/o }\end{array}$ & $\begin{array}{l}\text { Had a difficult adaption period, } \\
\text { otherwise tolerable. Tongue coating } \\
\text { disappeared. }\end{array}$ & $\begin{array}{l}\text { diarrhoea, low energy during } \\
\text { the first } 2 \text { weeks. }\end{array}$ & $\begin{array}{l}\text { Weight after } \\
\text { carnivore diet } \\
\text { not recorded. }\end{array}$ \\
\hline $\begin{array}{l}\text { Pat.5 } \\
\text { Female } \\
23 \text { y/o }\end{array}$ & $\begin{array}{l}\text { Enjoyed the diet. Less headache, joint } \\
\text { pain and stomach pain. }\end{array}$ & None & $\begin{array}{l}\text { Same weight } \\
\text { as before }\end{array}$ \\
\hline $\begin{array}{l}\text { Pat.6 } \\
\text { Female } \\
49 \mathrm{y} / \mathrm{o}\end{array}$ & $\begin{array}{l}\text { Enjoyed the diet and continued with a } \\
\text { low carbohydrate, low fibre diet. Hair } \\
\text { and nail quality increased. }\end{array}$ & $\begin{array}{l}\text { Adjustment problems with } \\
\text { diarrhoea, rapid weight loss } \\
\text { during the first week. }\end{array}$ & Approx. 10 kg \\
\hline
\end{tabular}




\section{Exploratory Analyses}

With an extensive amount of laboratory analyses available for each patient we checked for other interesting findings besides SIBO test results. According to the measurements there were no distinct evidence from stool tests that SIBO caused unsatisfactory digestion of fat or proteins, even though most patients had selfreported digestive issues. All patients had nutritional deficiencies according to the extensive blood and urine organic acids panels. Hippuric acid was present in the urine of all patients, except for one, and may be a marker of gut bacteria overgrowth [12], even though no clear reference interval seems to be acknowledged. The comprehensive stool test revealed elevated E.coli content in the colon in two of the patients, but no other SIBO-related bacteria or bacterial or parasite infections were found. E. coli is one of the major players associated with hydrogen dominant SIBO.[13]

\section{Limitations}

The lactulose breath test has been shown to have a higher sensitivity but a lower specificity, as compared to the glucose breath test.[14, 15] We argue that the test with the higher sensitivity (lactulose breath test) is a better choice for SIBO detection in a functional medicine clinic, especially when the short term dietary treatment can be considered having few side effects.[16, 17] However, because of a lot of contradicting reports about the effectiveness of the various types of SIBO testing techniques[18], this may be a weakness in this report.

This was an unsupervised dietary intervention. Even though the patients were highly motivated it is impossible to verify to what degree they were following the diet. Further, even though SIBO tests were adequately timed before and after the diet intervention, all additional tests were spread out rather than perfectly timed before and after the carnivore weeks.

All subjects were females, reflecting that $70 \%$ of our patients are female. Commercially available diagnostic tools for hydrogen sulphide SIBO was not present before October 2020.

\section{Discussion}

This retrospective case report from a functional medicine [7] clinic, is to the best of our knowledge the first published evidence that a short term exclusively animal based, zero carbohydrate carnivore diet can normalize hydrogen positive lactulose SIBO breath tests. The patients chose to eat this therapeutic diet from two to six weeks of time. The rationale for this dietary approach was the fact that the most clinically successful diet for the treatment of SIBO published so far, the elemental diet, can result in $80-84 \%$ remission of SIBO in only 2-3 weeks of treatment. [19] As shown in this paper, our clinical experience with a zero-carb carnivore diet reveals an equally high success rate, but with the added benefit of being more palatable and more suitable for hypoglycaemic patients and patients with insulin resistance. A carnivore diet is cost effective, readily available, and according to our observations results in better satisfaction after meals and decreases cravings for sweets. 
Conventionally, a double peak in lactulose hydrogen breath test (one due to SIBO and the other from colonic fermentation) is considered diagnostic of SIBO. Pimentel et al suggested that a rise in breath hydrogen 20 ppm above basal levels within 90 minutes after ingestion of lactulose should be considered a positive test.[20] Following this rationale in conjunction with the fact that all patients had gastrointestinal issues and nutritional deficiencies [21] it is likely that the patients indeed suffered from SIBO. However, patient 3 and 5 lacked a distinct double peak while simultaneously suffering from chronic constipation. We acknowledge this as an interesting observation as some data also suggest that patients with constipation have different breath test results than patients with IBS or diarrhoea.[22] Patients 3 and 5 also had the most prominent reductions in methane gas from the diet intervention which may lead to less constipation.

According to our observations as well as the patients' own experiences, the diet intervention resulted in resolution of gut issues. Several patients experienced additional benefits such as weight loss and increased well-being, even though the first week of a zero-carbohydrate diet can be tough for anyone not used to limiting their carbohydrate intake. In comparison with the elemental diet, the carnivore diet provides more satiety, biocompatible nutrients, and general enjoyment as there is no caloric restriction and the patients' have freedom to choose their daily food intake as long as they follow the guidelines. This makes the diet more endurable than the elemental diet while seemingly being just as effective. Unfortunately, meat, organ meats and animal fat has gotten a bad rap due to weak epidemiological studies linking these food products to heart disease and cancer. [23] However, it is probably safe to say that very few of the heavy meat eaters in these studies, ate a zero carbohydrate, zero fibre, carnivore diet. Much more factors come into play in the development of lifestyle diseases such as smoking habits, alcohol intake, training frequency and overall quality of life. Although small case reports [24] has been published, no large, controlled studies have been made on the safety of following a carnivore diet for longer periods of time. In the present material, no serious side-effects were detected in following the diet for a few weeks of time as an elimination diet or for SIBO eradication.

\section{Conclusion}

The present case report of six patients from our functional medicine clinic shows for the first time (Fig. 1) that a zero carbohydrate, zero fibre, carnivore diet, have the potential to normalize hydrogen positive SIBO breath tests in a comparable manner to the elemental diet, but with the added benefit of being more palatable and easier to endure. The presented data points to a short-term carnivore diet as an evolutionarily sound, cost effective and readily available addition to our clinical therapeutic options for SIBO, which merits further evaluation in larger studies.

\section{Abbreviations}

SIBO Small Intestinal Bacterial Overgrowth

FODMAP Fermentable Oligosaccharides, Disaccharides, Monosaccharides And Polyols

IBS Irritable Bowel Syndrome 
MMC Migrating Motor Complex

IgG Immunoglobulins G

5-HIAA 5-Hydroxyindoleacetic acid

OCD Obsessive Compulsive Disorder

CRP C-reactive protein

\section{Declarations}

\section{Ethics approval and consent to participate}

Not applicable

\section{Consent for publication}

This case report is a retrospective review of ongoing clinical work. All patients were regular patients at the functional medicine clinic FunMed in Gothenburg, Sweden, and consented to scientific publication of the collected data in writing.

\section{Availability of data and material}

Not applicable

\section{Competing interests}

The authors declare no conflict of interest.

\section{Funding}

This research received no external funding.

\section{Author Contributions}

PM was the clinician in charge of this study. He managed the patients, the test interpretation, and their experimental dietary intervention, as well as contributed as an author. $\mathrm{MJ}$ and $\mathrm{AE}$ performed article research and article writing. All authors reviewed and approved of the manuscript.

\section{Acknowledgements}

We thank the patients for allowing us to share their details and for their bravery in trying a highly unconventional diet.

\section{References}

1. Bures J, Cyrany J, Kohoutova D, Förstl M, Rejchrt S, Kvetina J, ... \& Kopacova M. Small intestinal bacterial overgrowth syndrome. World journal of gastroenterology: WJG. 2010;16(24):2978.

2. Peralta S, Cottone C, Doveri T, Almasio PL, Craxi A. Small intestine bacterial overgrowth and irritable bowel syndrome-related symptoms: experience with Rifaximin. World journal of gastroenterology: WJG. 
2009;15(21):2628.

3. Rao SS, Bhagatwala J. (2019). Small intestinal bacterial overgrowth: Clinical features and therapeutic management. Clinical and translational gastroenterology, 10(10).

4. Ghoshal UC, Shukla R, Ghoshal U. Small intestinal bacterial overgrowth and irritable bowel syndrome: a bridge between functional organic dichotomy. Gut Liver. 2017;11(2):196.

5. Quigley EM. The spectrum of small intestinal bacterial overgrowth (SIBO). Current Gastroenterology Reports. 2019;21(1):3.

6. Deloose E, Janssen P, Depoortere I, Tack J. The migrating motor complex: control mechanisms and its role in health and disease. Nature reviews Gastroenterology hepatology. 2012;9(5):271.

7. Beidelschies M, Alejandro-Rodriguez M, Ji X, Lapin B, Hanaway P, Rothberg MB. Association of the functional medicine model of care with patient-reported health-related quality-of-life outcomes. JAMA network open. 2019;2(10):e1914017-7.

8. Willmann M, Vehreschild MJ, Biehl LM, Vogel W, Dörfel D, Hamprecht A, ... Peter S. Distinct impact of antibiotics on the gut microbiome and resistome: a longitudinal multicenter cohort study. BMC Biol. 2019;17(1):1-18.

9. Agam A, Barkai R. (2018). Elephant and mammoth hunting during the Paleolithic: a review of the relevant archaeological, ethnographic and ethno-historical records. Quaternary, 1(1).

10. Wißing C, Rougier H, Baumann C, Comeyne A, Crevecoeur I, Drucker DG, ... Matthies T. Stable isotopes reveal patterns of diet and mobility in the last Neandertals and first modern humans in Europe. Scientific reports. 2019;9(1):1-12.

11. Rezaie A, Buresi M, Lembo A, Lin H, McCallum R, Rao S, Pimentel M. Hydrogen and methane-based breath testing in gastrointestinal disorders: the North American Consensus. Am J Gastroenterol. 2017;112(5):775.

12. Calvani RICC, Miccheli A, Capuani G, Miccheli AT, Puccetti C, Delfini M, ... \& Mingrone G. Gut microbiome-derived metabolites characterize a peculiar obese urinary metabotype. Int J Obes. 2010;34(6):1095-8.

13. Gabriela Leite W, Morales S, Weitsman S, Celly G, Parodi R, Mathur GM, Barlow R, Sedighi., Maria Jesus Villanueva Millan, Ali Rezaie, Mark Pimentel. (July 9, 2020). The duodenal microbiome is altered in small intestinal bacterial overgrowth. PLoS ONE 15(7): e0234906.

14. Ghoshal UC. How to interpret hydrogen breath tests. Journal of Neurogastroenterology motility. 2011;17(3):312.

15. Simren M, Stotzer PO. Use and abuse of hydrogen breath tests. Gut. 2006;55(3):297-303.

16. Riordan SM, Mclver CJ, Walker BM, Duncombe VM, Bolin TD, Thomas MC. (1996). The lactulose breath hydrogen test and small intestinal bacterial overgrowth. American Journal of Gastroenterology (Springer Nature), 91(9).

17. Ruscio M. (2019). Is SIBO A Real Condition?. Alternative Therapies in Health \& Medicine, 25(5).

18. Rana SV, Sharma S, Kaur J, Sinha SK, Singh K. Comparison of lactulose and glucose breath test for diagnosis of small intestinal bacterial overgrowth in patients with irritable bowel syndrome. Digestion. 
2012;85(3):243-7.

19. Pimentel M, Constantino T, Kong Y, Bajwa M, Rezaei A, Park S. A 14-day elemental diet is highly effective in normalizing the lactulose breath test. Digestive diseases sciences. 2004;49(1):73-7.

20. Pimentel M, Chow EJ, Lin HC. Eradication of small intestinal bacterial overgrowth reduces symptoms of irritable bowel syndrome. Am J Gastroenterol. 2000;95:3503-6.

21. Quigley EM, Murray JA, Pimentel M. AGA clinical practice update on small intestinal bacterial overgrowth: expert review. Gastroenterology. 2020;159(4):1526-32.

22. Soares ACF, Lederman HM, Fagundes-Neto U, de Morais MB. Breath hydrogen test after a bean meal demonstrates delayed oro-cecal transit time in children with chronic constipation. J Pediatr Gastroenterol Nutr. 2005;41(2):221-4.

23. Vernooij, R. W., Zeraatkar, D., Han, M. A., El Dib, R., Zworth, M., Milio, K., ... Swierz,M. J. (2019). Patterns of red and processed meat consumption and risk for cardiometabolic and cancer outcomes: a systematic review and meta-analysis of cohort studies. Annals of internal medicine, 171(10), $732-741$.

24. Tolstoi E. The effect of an exclusive meat diet lasting one year on the carbohydrate tolerance of two normal men. Incorporated: Waverly Press; 1929.

25. Conway T, Cohen PS. Commensal and Pathogenic Escherichia coli Metabolism in the Gut. Microbiol Spectr. 2015 Jun;3(3):10.

\section{Figures}



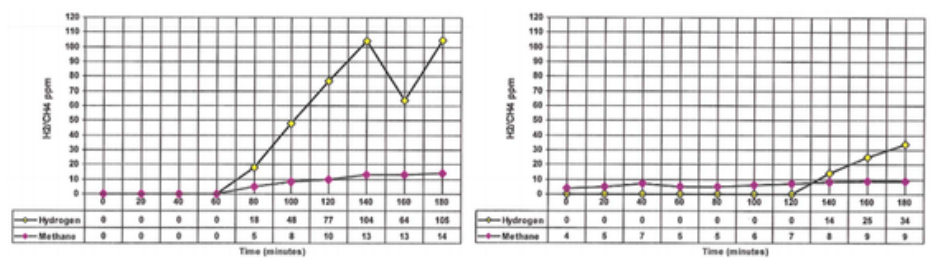

Pat.1 (carnivore diet 6 weeks)

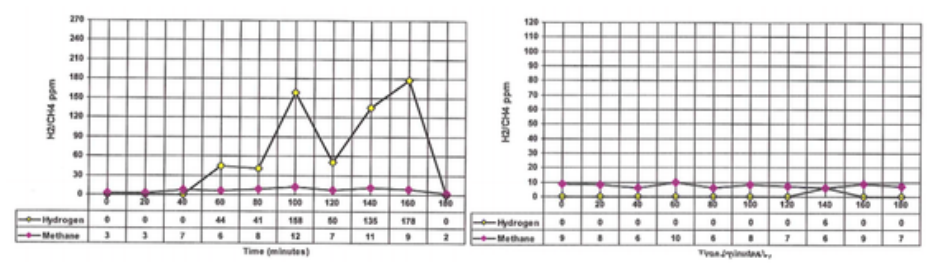

Pat.2 (carnivore diet 4 weeks; Note scale variation.)
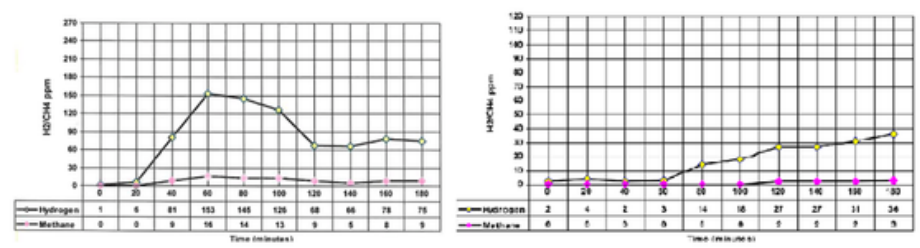

Pat.3 (carnivore diet 2 weeks. Note scale variation.)
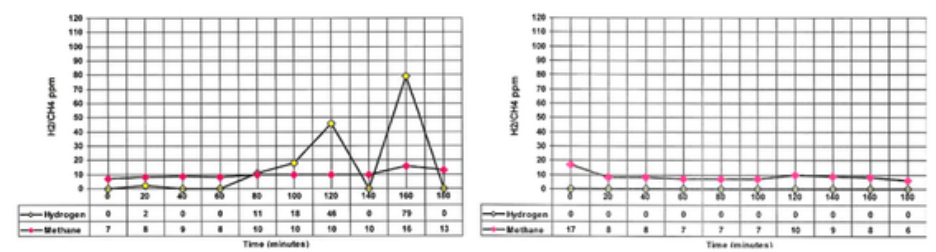

Pat.4 (carnivore diet 4 weeks)
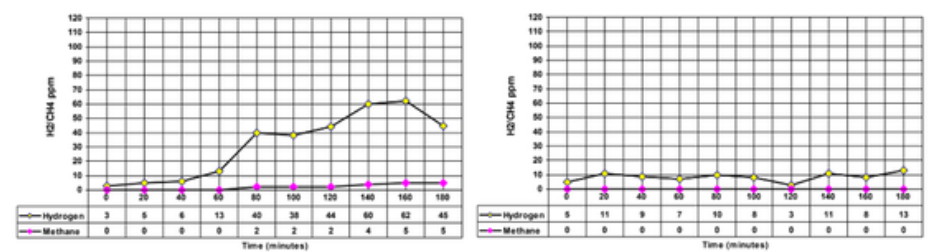

Pat.5 (carnivore diet 5 weeks)
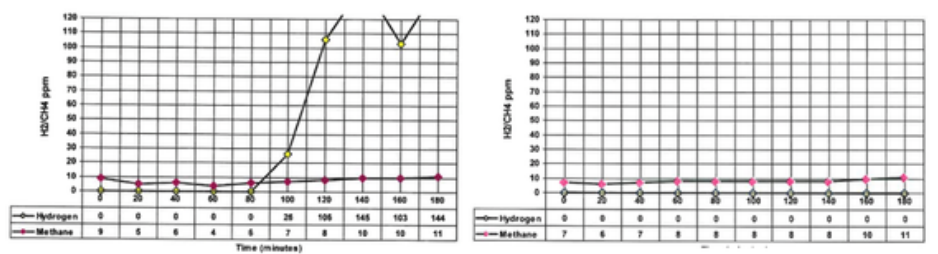

Pat.6 (carnivore diet 6 weeks)

\section{Figure 1}

The graphs illustrate the before and after test results for the lactulose hydrogen/methane SIBO breath test for each patient. 